\title{
Dynamic Intercorrelations between Transport/Traffic Infrastructures and Territorial Systems: From Economic Growth to Sustainable Development
}

\author{
Serban Raicu, Dorinela Costescu* (D), Mihaela Popa (D) and Vasile Dragu \\ Transport, Traffic and Logistics Department, Polytechnic University of Bucharest, Splaiul Independentei 313, \\ 060042 Bucharest, Romania; serban.raicu@upb.ro (S.R.); mihaela.popa@upb.ro (M.P.); vasile.dragu@upb.ro (V.D.) \\ * Correspondence: dorinela.costescu@upb.ro
}

check for

updates

Citation: Raicu, S.; Costescu, D.;

Popa, M.; Dragu, V. Dynamic

Intercorrelations between

Transport/Traffic Infrastructures and

Territorial Systems: From Economic Growth to Sustainable Development. Sustainability 2021, 13, 11951.

https://doi.org/10.3390/

su132111951

Academic Editor: Antonio Boggia

Received: 24 September 2021

Accepted: 27 October 2021

Published: 28 October 2021

Publisher's Note: MDPI stays neutral with regard to jurisdictional claims in published maps and institutional affiliations.

\begin{abstract}
The correlations between investments in transport infrastructure and territorial development continue to concern public authorities. They are responsible for optimising the allocation of financial resources, and they are interested in the correct short- and long-term estimations of investments in transport infrastructure's consequences for development. The direct and indirect effects of transport infrastructure are present in the socio-economic assessment methodologies of projects. Despite the recorded progress, uncertainties remain in technical assessments, especially socio-economic ones, and they do not remove decision-makers' concerns regarding the necessity and appropriateness of investments. Based on these aspects, this paper aimed to clarify the effects of new infrastructure on socio-economic development.
\end{abstract}

Keywords: transport infrastructures; economic development; organisational structures; activity systems; traffic logic

\section{Introduction}

For a long time, studies have targeted emphasising the relationships between transport infrastructure and economic development. Approximately 240 years ago, in an analysis of a navigation channel, Adam Smith noticed the connections between infrastructure, transport, exchanges and economic growth. Since then, many studies have examined the intercorrelations between investments in transport infrastructures and land use [1-5].

Initially, research was addressed to determine the impact of transport infrastructure on economic growth $[1,6]$. Then, the evolution caused by technological progress (sources and consequences of urbanisation, motorisation and globalisation) marked the expansion and diversification of the transport/traffic infrastructure and the entire technical infrastructure of society. Consequently, research has extended to assess the positive and negative effects (at the local and global levels) of investment in transport/traffic infrastructure in correlation with the entire public investment in a specific area [7-11].

However, the answers to many questions on this topic have remained equivocal [2,12-16]. The enhancements of economic analyses that simultaneously evaluate economic, social and environmental impacts have amplified the decision framework and the uncertainties of local and central decision makers related to investment allocation for technical infrastructure and, particularly, for transport/traffic infrastructure [17]. In the case of new technical infrastructure, many social and environmental aspects (which need to be quantitatively included in an efficiency assessment) condition the investment $[16,18]$. For example, the effects on employment, health, access to the locations of interest, greenhouse emissions, security, urban environment, heritage and user comfort need to be quantitatively and monetarily considered for traffic infrastructure [19]. These evaluations increase the complexity of the decision-making process.

Understanding and awareness of the multiple threats to the survival of the Earth bring to the fore the social and ecological limitations of growth [20-22]. From this view, 
the interrelationships between transport/traffic infrastructure and development must be examined. The territorial dimension of transport/traffic infrastructure involves the transition from the effect's logic to the interactions' logic [23,24].

Moreover, to increase the resilience of the territorial system, the approach of the technical infrastructures of society as an aggregate of interconnected systems has been recommended recently.

The functions of the territorial system (among which the quality of life is considered primordial) depend not only on the transfer of material flows on traffic networks but also on the performances of other technical infrastructure networks for material, energy and information flows. Therefore, a unitary approach to all these technical networks is necessary for the territorial system's design, operation and functioning [25]. Holistic examinations, corresponding to the pluri-relational characteristic of the technical networks of the society, must surpass the restricted technical visions, addressed separately on each type of network according to its physical phenomena. Building resilient and sustainable infrastructure is an emergency $[11,26]$. Climate change is already disrupting the life of the planet.

Based on sustainable development requirements, the paper aimed to bring additional clarifications regarding the effects of new infrastructures on socio-economic evolution. The following section surveys relevant literature to emphasise the role of traffic infrastructures in land use and to formulate a theoretical framework. It exposes that traffic infrastructure enhances accessibility and could support development, but sustainable performances are gained only if public actions complement infrastructure investments (in a holistic manner) and stimulate an environment for innovation and growth.

Therefore, a comprehensive taxonomy of the impact of an investment in a specific infrastructure (integrating the diversity and complexity of the region) should precede decisions. The third section explains the correlations between the territorial system's geographical, economic, social and political attributes and the performances of traffic infrastructures. Relative to different periods and subjects, territory and development have been perceived differently. Section 4 analyses the economic growth during the "glorious years" of the Industrial Revolution (considered a historical milestone in the evolution of society). It reveals that, now, development is different than economic growth expressed in gross domestic product (GDP). Adding to the economic component are the social and environmental ones, and development can be assessed by the composite indicators of the quality of life. The importance of the present criteria of sustainable development is underlined. Section 5 explains how in addition to the delays in assimilating technological progress related to the Industrial Revolution, the social, economic, political and natural specificities of the regions differentiated economic growth.

Significant changes in transport technologies are prefigured in the next decades [27]. The presented analysis focused on understanding the particularities of development related to temporal and regional specificities. It represents the first stage of research that aims to improve the methodology for evaluating new traffic infrastructures via sustainable development and territorial particularities.

\section{Theoretical Framework}

As components of the technical network infrastructures of society, traffic infrastructure plays a fundamental role in structuring territory. It represents public property because it meets the conditions of non-exclusivity and non-rivalry (within certain limits). Based on the Saint-Simonian principle, specialists and politicians consider transport (in exchange relationships) a factor of progress or, at least, an explanatory factor for land use and urban planning.

The correlation between traffic infrastructure investment and economic growth has been an intensely debated topic for a long time. Strategies based on the fact that economic growth is dependent on the transport system assume that the elasticity of the benefits of 
transport investments is significant $[28,29]$. On the other hand, several studies could not reveal the direct relationship between investment and the level of regional economies [30,31].

The methods applied to assess the impact of traffic infrastructure investments on economic development can be grouped into three categories: multiplier effects, cost-saving effects and wider economic consequences [32].

Traffic infrastructure encourages the transports of goods and people, which facilitates trade and contributes to general development $[5,17,33]$. Suppose the correlations between traffic infrastructures, exchanges/transports/travel, territorial system and development are considered beside their productive characteristic. In that case, traffic infrastructures must be included in the category of collective (mixed) public property that brings specificity to the socio-economic analysis and justifies the involvement of the state. Obviously, other attributes of traffic infrastructure reason the strategic role of the state: the considerable value of investments, land consumption, harm to the natural environment, substantial time of functioning, relatively long period for design and construction, indivisibility and gradual assimilation of the capacity increase and natural monopoly-generally with increasing average and marginal outputs [16].

Technical, political/strategic and economic grounds motivate the policy of the state (functions of allocation, redistribution and macroeconomic adjustment) in the domain of transport and implicitly of the development of traffic infrastructures, directed to the role of public capital in economic growth, quality of life and environmental conservation $[17,20,34]$.

There is a causal relationship between public investment in traffic infrastructure development and investment in other economic sectors. The immobilised capital in infrastructure can inhibit investments in different sectors of the area. Periods with significant investments in traffic infrastructure are followed by periods in which investments in other sectors predominate.

The dynamics of an economy, like any other organism, are naturally affected by fluctuations. Several economic models reveal different periodicities. Besides the shortterm oscillations studied by Keynes, Jay Forrester and the Systems Dynamics Group have identified three distinctive cycles [35]:

- A five- to seven-year cycle, slightly influenced by changes in interest rates and other Keynesian manipulations, reflecting the interaction between employment level and available reserves/supplies;

- An eighteen-year cycle related to the investment process;

- A fifty-year cycle with the most substantial effect on the economy, with a completely different nature, reflecting technological evolution.

Traffic infrastructure is only one factor that determines the development of the territorial system by enhancing accessibility [36,37]. The development is additionally dependent on invisible and intangible capabilities that public actions in favour of innovation must stimulate. Technological and commercial innovations are indispensable conditions [38,39]. The restructuring/modernisation/development of a traffic infrastructure could positively impact on the micro- and mesoscale if a favourable development potential has already been generated in a related area.

As a factor of improvement in accessibility [29,36], traffic infrastructure causes indirect and conditional effects on development because it represents:

- A resource for production such as capital and a labour force;

- A factor increasing individual utility (perceptible by cost, duration, safety, comfort, etc.), but the collective utility is the one that determines development;

- A factor predisposed to influence the territorial dynamics differentiated according to the effects and the relationship between the organisational structure and the spatial one.

An evaluation of the accessibility of places [40-43] can be extended to the identification of the volume and nature of traffic flows assigned to the infrastructure and developed services. However, it does not include information on the flow generation in the places 
of the territorial system, because the traffic infrastructure does not represent a sufficient condition for producing positive economic and social dynamics.

This conclusion [44] has contributed to the decrease in enthusiasm regarding the benefits of all investments in new traffic infrastructures and, frequently, this conclusion has been brought to the fore, especially because quasi-certain features of the extensive road and railway infrastructures have still been linked to economic growth due to the mixture of neo-Keynesian benefits ("the unconditionally positive role of all public works"), technological euphoria ("faster and faster") and advantages associated with the unification of the European market.

Structuring effects are defined as the positive effects of traffic infrastructure on economic development. Their assessment remains a complicated issue mainly because such structuring effects suggest that the cause-effect relationships would occur immediately and unconditionally in terms of activities, local and regional development and population location.

The term structuring effects, primarily used for transport (and then for other technical networks, e.g., for energy and information flows), represented a leitmotif of the late 19th century. In all cases, the specific uses of the term, devoid of generality and without references to the consequences for the development of the territorial system, mainly focused on the differentiated accessibility provided by a new traffic infrastructure in a specific area $[40,41]$.

The empirical ex-post impact studies on the effects of new infrastructures on local and regional development often contradict the expected positive socio-economic dynamics $[31,45]$. However, the subliminal inversion in the cause-effect relationship persists. Explaining the cases in which new infrastructures have had a null or negative role in land use remains debatable [46].

The terminology used to describe the effects of infrastructures on development is still very diverse. Therefore, a comprehensive taxonomy of the impact of an investment in a specific infrastructure should precede the systematisation actions. This taxonomy should include elements related to the organisational structure of the territory with its dual nature (material and symbolic or ideal), i.e., those elements that integrate the diversity and complexity of the region in its political, economic, social and environmental extents [47].

The correlation between investments in traffic infrastructures and territorial development remains an open issue for research and of significant interest for public authorities [16,48-50]. Indirect secondary, derivative effects that aim at the consequences on the territorial system are open topics for research. However, even in the field of infrastructure project assessment concerning direct effects, further research is still required for technical evaluation (marked by the uncertainty of the sizing of capacities in the conditions of irregular demand) and, especially, for socio-economic assessment (which must also include the hedonic costs).

\section{Conditions for Economic Growth}

The evaluation of the consequences of the traffic infrastructures is conditioned by the reports related to territory and the theoretical representation associated with development $[3,16,50]$.

Historical examples provide convincing arguments for the correlations between a specific natural traffic infrastructure and the development of a multimillennial human society, e.g., the Nile with its flowing course from south to north and with the dominant winds from north to south favoured navigation with a decisive role for exchanges within the territorial system during all historical periods. This longest watercourse on the Earth, with its resources, fertilising overspills complemented by irrigation networks for agriculture, represents a convincing illustration of the perennial interrelationships between traffic infrastructure, territorial system and development of human civilisation. The historical cases demonstrate that a neutral, bland spot of land, without any other attribute than distance, has no significance in the infrastructure-territory-development relationship. 
In a simple analysis, the role of infrastructure is linked to a decrease in transport/travel costs or an increase in accessibility [51]. The territorial system (characterised by complex relationships between economic stakeholders, inhabitants, resources and activities) is excluded from the analysis. The examination is limited to the direct mechanical effects of infrastructure on development, questionable results and, sometimes, even contested [39,52-54]. Therefore, to clarify the role of traffic infrastructure in development, the inseparable correlation of exchanges/transport with the geographical, economic, social and political attributes of the territorial system and with the performances of traffic infrastructure (existing or possible through development) must be observed (Figure 1).

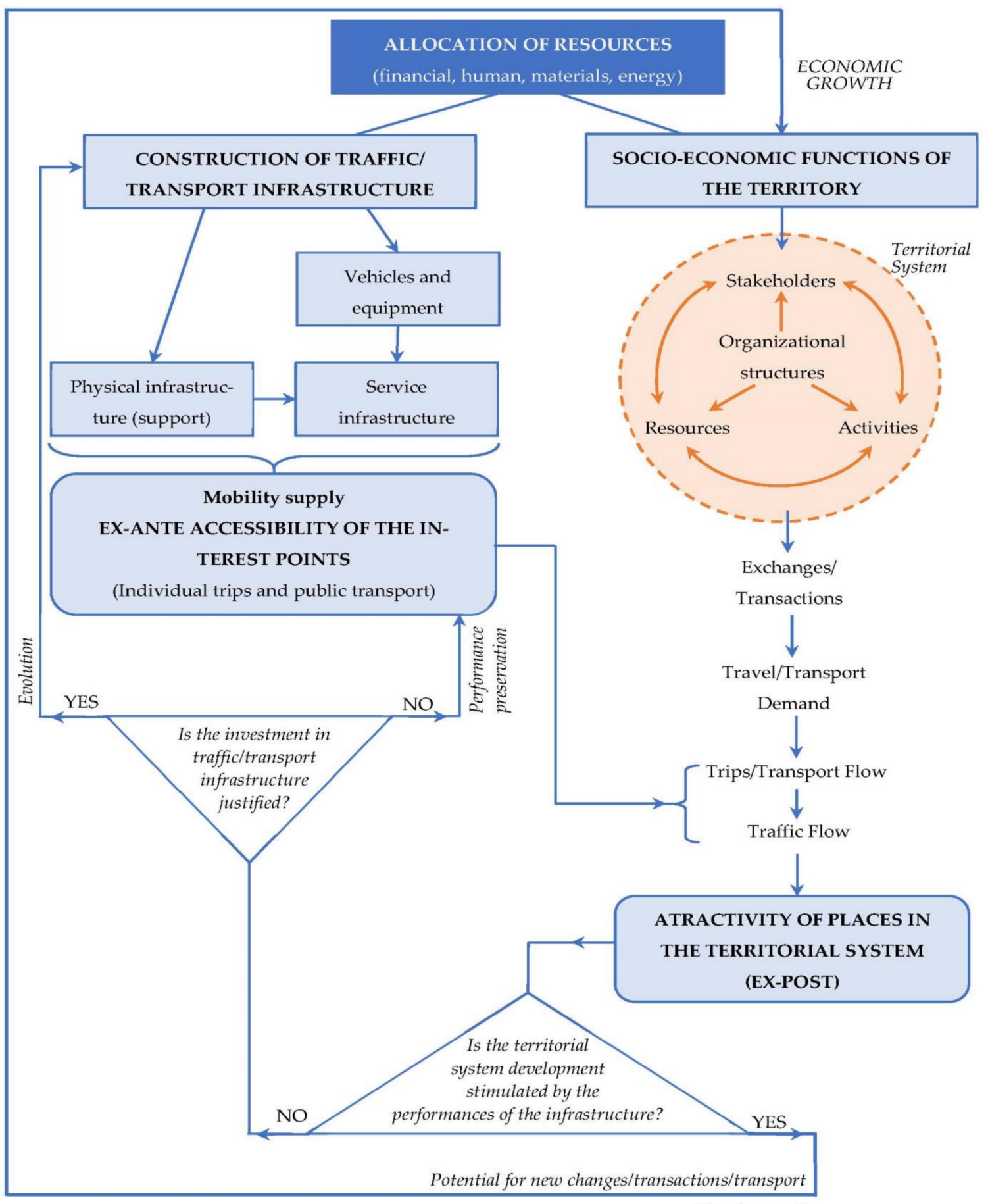

(Development)

Figure 1. Correlations between traffic infrastructure, territorial system, exchanges/transactions/transport, and economic development. 
The components of the territorial system can be grouped into three main classes: stakeholders, resources and activities/relationships. The stakeholders are considered essential in how the consequences of traffic infrastructure are capitalised in the development scheme [4]. Through the relationships among them, the stakeholders control, coordinate the resources and perform activities to produce goods and services for the benefit of the territorial system. The relationships between resources and activities define a complex organisational structure, a system of interdependent, effective activities that use a specific set of resources.

In this frame, the traffic infrastructure is a resource for production such as capital and labour force, and transport is a service required by the stakeholders for exchanges inside the territorial system.

Based on the connections provided by the traffic infrastructure, a solid relationship is established between the organisation of activities and the territory. Set on the interaction between stakeholders, the organisational structure of the territorial system is perceived as the result of a collective assembly in which technological innovation (as a determining factor of development) is or is not present [14].

Without being postulated in advance, the territory is analytically formalised by articulating organisational forms, i.e., by the ability to share knowledge and information, to organise interactions (as complementary relations) for the physical transfer of flows.

The organisational structure, essential for the functioning of the territorial system, involves interactions that generate flows of information, people, raw materials and goods. Therefore, the role of transport infrastructure and services in the performance of the territorial system must be evaluated. This evaluation must be performed only in correlation with the configuration of the organisational network.

A particular type of organisational network configuration corresponds to specific traffic logics, types of productions and strategic flows, specific logistics and technical and economic interventions in the modes of transport (Table 1).

Table 1. Characteristics of the traffic logic.

\begin{tabular}{|c|c|c|c|c|}
\hline $\begin{array}{l}\text { Traffic } \\
\text { Logic }\end{array}$ & Type of Production & Strategic Flow & Logistics & Modes of Transport \\
\hline Industrial & $\begin{array}{l}\text {. Intermediary goods, } \\
\text { slightly differentiated } \\
\text {. Large series (economy } \\
\text { of scale) } \\
\text {. Specialisation of } \\
\text { production sites }\end{array}$ & $\begin{array}{l}\text { Materials, goods (massive } \\
\text { and standardised flow) }\end{array}$ & $\begin{array}{l}\text { Industrial logistics } \\
\text { based on cost criteria }\end{array}$ & $\begin{array}{l}\text { Externalised transport } \\
\text { (general or specialised) } \\
\text {. All modes of transport } \\
\text { but mainly modes } \\
\text { appropriate to } \\
\text { mass transports }\end{array}$ \\
\hline Flexible & $\begin{array}{l}\text { - Consumer goods } \\
\text { - Mass production (large } \\
\text { and average series) but } \\
\text { differentiated (product } \\
\text { ranges with a large } \\
\text { number of sorts) }\end{array}$ & $\begin{array}{l}\text { - Information } \\
\text { - Goods flow (rapid, } \\
\text { frequent and fractionated) }\end{array}$ & $\begin{array}{l}\text { - Complex logistics } \\
\text { (associated with rapid } \\
\text { transport) based on } \\
\text { reliability and flexibility } \\
\text { criteria (frequent } \\
\text { changes in logistics) }\end{array}$ & $\begin{array}{l}\text {. Externalised general } \\
\text { transport } \\
\text {. High frequencies } \\
\text {. Mainly road transport } \\
\text {. Marginal railway } \\
\text { transport }\end{array}$ \\
\hline Professional & $\begin{array}{l}\text {. Unique product or small } \\
\text { series } \\
\text {. Production on demand, } \\
\text { extremely differentiated, } \\
\text { even dedicated } \\
\text {. Specific knowledge }\end{array}$ & $\begin{array}{l}\text {. Knowledge } \\
\text {. Low goods flow }\end{array}$ & $\begin{array}{l}\text {. Basic logistics } \\
\text {. Small scale, frequently } \\
\text { dedicated } \\
\text {. Without logistic } \\
\text { externalisations }\end{array}$ & $\begin{array}{l}\text { - Partially internalised } \\
\text { - Movements on circuits } \\
\text {. Exceptional transports } \\
\text { - Mainly road transport } \\
\text { - Air transport for urgent } \\
\text { expeditions }\end{array}$ \\
\hline
\end{tabular}


Table 1 shows that among the organisational structures of the territorial system, there are essential differences regarding the role of the infrastructures of the service (transport) network that are supported by the physical network of the traffic infrastructure.

Relative to the traffic logics (industrial, flexible and professional), these differences mean specific logistic structures, infrastructures and transport practices.

Thus, in the logic of industrial traffic (e.g., corresponding to the metallurgical or chemical industry), the transit capacities of traffic infrastructures are essential for the organisation of massive flows based on optimisations in terms of transport costs. On the other hand, in the logic of flexible traffic (e.g., corresponding to the clothing or agri-food industry), the decisive role belongs to the organisational capacity of the system to ensure the flow of goods in compliance with the requirements of the beneficiaries.

The crucial role of the organisational capacity of the territorial system is even more evident in the case of the logic of professional traffic (small series or custom production) in which the cost and the distance lose importance. Thus, the role of the transit capacity of infrastructure relative to the size of the transferred flows is insignificant.

The traffic infrastructure and the transport activity adjusted to the requirements of an organisational structure appropriate to a specific traffic logic is also the expression of a coordination activity particular to the various types of logistics.

In the frame of each type of logic, the duality of transport-organisation (consolidation of demands, transport and traffic flows) requires analysing the role of traffic infrastructures in the coordination of network activities, further than the fundamental analysis of accessibility. Traffic infrastructure is a physical vector of the organisational network structure, conditioned by the emergence of the demand to travel. Consequently, the role of traffic infrastructure in territorial dynamics must be relativised.

Hence, not the binomial traffic infrastructure-development (or structuring effects of traffic infrastructures) but trinomial traffic infrastructure-territorial system-development should focus on the impact of development of the territorial system driven by investment in traffic infrastructure.

This type of research must provide the extent to which traffic infrastructure determines the differentiated development of the territorial system, i.e., it emphasises the necessity and opportunity to use public funds for investment in that traffic infrastructure appropriate to a particular organisational structure that corresponds to the maximum effects for socioeconomic development.

\section{Analysis of the Nexus between Economic Growth and Traffic Infrastructures}

Public authorities are responsible for strategies for the implementation of new transport/traffic infrastructures. Mainly, the substantial value of the investments and the state's right to decide to use the jurisdictional land according to the public's interest justify assigning this role. The effects of generated economic growth support the investment. Since the 19th century, the binomial "infrastructure-development" has underlined the financial calculation for prioritising the allocation of budgetary resources. Since then, the reversibility of the relationship has been revealed. As the presented analysis shows, the Machinist Revolution stimulated the emergence of transport infrastructure for supply/distribution and daily mobility of labour. At the same time, the new infrastructures, through the increased accessibility, originated the exchanges and the spatial proximity of the stakeholders. However, especially, this connection with the territory is missing from the mentioned binomial. Therefore, the binomial was replaced with the interrelationships "transport/traffic infrastructure-exchanges/travel/transport-territorial system-development". The particularities of the territorial system condition the role of infrastructure in development. Infrastructure is a necessary condition for development but not sufficient. The role of infrastructure is relativised according to the traffic logic and the organisational capacity of the stakeholders.

Based on the identification and use of new resources, the assimilation of scientific and technological progress, the capitalisation of favourable political and commercial circumstances and the joint actions of stakeholders lead to productivity increases over time. 
These have consequences both in the material and in the symbolic component of the territorial system. Often, the positive dynamics of the territorial system generate remarkable changes in the size and structure of traffic flows. As a result, justified stress appears to increase the performance of traffic and/or transport networks. The development of the territorial system is conveyed as a priority for restructuring the traffic infrastructure and/or related services.

Since the Industrial Revolution in the 19th century, communication infrastructure and vehicle causality have accompanied the paradigm of progress: railways and then high-speed trains, roads and then highways, trams and then subways.

A historical retrospective on the transition toward industrial production in England (begun around 1760) could show how economic growth was the generator of expansion toward new anthropogenic traffic/transport networks. Firstly, the mechanisation of textile production was developed, then of steel and coal mining. Those three sectors reciprocally influenced economic growth. The industrialisation of spinning and weaving processes required iron and steel machines, making it essential to extract iron and coal ores as a substitute for wood, which became increasingly rare [55]. In England, coal and iron ores were found in sufficient quantities. In addition, numerous watercourses valid for exchanges in industrial production were accessible.

However, many other factors stimulated industrial production: the intellectual elite; the modernisation of agriculture (with crop rotation, which by increasing productivity played a crucial role in laying off labour and encouraging the Industrial Revolution); the inland waterway network, complemented by the Stockton-Darlington railway (in 1825), as a symbolic link between iron and coal; the consolidation of the unified internal market. The development of external trade relationships also favoured the evolution of England (initially for manufactured products, then also for industrial goods) and the expansion of colonies (followed by so-called triangular trade). With raw material brought by sea from colonies, the textile industry was developed in several English regions: Lancashire and Manchester, which became the capital of the new liberalism. Liverpool was expanded as the most important port for exports. Textiles turned into the most significant export products in England, which continued the campaign for free trade [56].

The example presented for England demonstrated that the accessibility of maritime and inland waterway transport was only a favourable condition for the economic development that had led to the emergence of railway transport. There are many geographical areas where similar geographical conditions have not led to growth.

Industrial development in England also produced a massive transfer of workforce to cities. For example, in London, the population grew from 1 million in 1800 to over 6.2 million in 1900. The cities became overcrowded, and the living and working conditions were difficult (80-90 work hours a week, in dusty atmospheres, with risk of accidents due to the unprotected machinery) [20,55-57].

Evidently, new travel requirements were recorded between cities and between residences and workplaces. The beneficiaries of the new forms of organisation had to find solutions for the massive traffic flows within and between cities. Those circumstances explained the building of the first railway line from Manchester to Liverpool (1830) for people transfer, the rapid expansion of the railway network and the operating of the first subway lines in the world (since 1863). The steam traction used for the first subway lines and the pollution from factories contributed to the degradation of the air in London. The atmosphere was so foggy that people needed artificial light from lanterns on the street and in buildings even during the day [57]. Under those conditions, morbidity was high (e.g., in poor areas of Manchester, life expectancy unprecedentedly decreased to only 17 years). However, starting in the last decades of the 19th century, the capacity of British society to be aware of the negative consequences of accelerated economic growth in social and environmental terms and the coherent actions of correction/repair must be highlighted.

The quoted examples show that the circumstances of the machinist period were essential for economic growth but with significant social and environmental costs (incriminating 
for non-compliance with the basic requirements of decent living and respect for the environment). They underline that the term "development" must now include the economic, social and ecological attributes requested by the sustainable development exigencies $[58,59]$. Depending on the various aspirations and understandings of well-being or quality of life, the specificity of "development" in different times and circumstances should be noted.

Empirical analyses at the international and national levels using cross-sectional and panel data sets were performed to identify the correlations between transportation improvement and economic growth $[17,31,45,50,51,60-64]$. The main classes of empirical approaches are aggregate production function (Cobb Douglas, Translog), cost function, vector autoregression analysis and endogenous growth models [17,50,65]. At the aggregate level, the long-run empirical study of 11 OECD countries over 130 years and 22 OECD countries over 40 years revealed that the social returns on investment in equipment substantially exceeded their private returns in the pre-war and the post-war periods [45]. Farhadi [50] applied the generalised method of moments method to analyse the growth impact of public infrastructure for 18 OECD countries during 1870-2009. The results revealed that even if the productivity effect of investment in transport infrastructure was reached, the magnitude of the influence was relatively minor compared to other variables. Agbelie [31] used three econometric methods (ordinary least squares, random effects and random parameters models) to analyse the relationship between transportation infrastructure expenditure and GDP from economies in 40 countries.

The following analysis reveals the dynamics of economic growth at the end of the 19th century and the beginning of the 20th century. The comparisons were based only on the GDP per capita (even presently, GDP is not an appropriate indicator for the level of quality of life in a territory and, from several points of view, it is debatable) [61,65-68].

\section{Results and Discussions}

The GDP dynamics of different European countries [69], presented in Table 2 and Figure 2, are eloquent for the effects of the Industrial Revolution on economic growth.

Table 2. Evolution of GDP per capita in European countries in the nineteenth and early twentieth centuries.

\begin{tabular}{|c|c|c|c|c|c|c|c|}
\hline \multirow{2}{*}{ Country } & \multicolumn{7}{|c|}{ Year } \\
\hline & 1800 & 1830 & 1850 & 1870 & 1890 & 1900 & 1913 \\
\hline Austria-Hungary & 200 & 240 & 275 & 310 & 370 & 425 & 510 \\
\hline Belgium & 200 & 240 & 335 & 450 & 555 & 650 & 815 \\
\hline Bulgaria & 175 & 185 & 205 & 225 & 260 & 275 & 285 \\
\hline Denmark & 205 & 225 & 280 & 365 & 525 & 655 & 885 \\
\hline France & 205 & 275 & 345 & 450 & 525 & 610 & 670 \\
\hline Finland & 180 & 190 & 230 & 300 & 370 & 430 & 525 \\
\hline Germany & 200 & 240 & 305 & 425 & 540 & 645 & 790 \\
\hline Great Britain & 240 & 355 & 470 & 650 & 815 & 915 & 1035 \\
\hline Greece & 190 & 195 & 220 & 255 & 300 & 310 & 335 \\
\hline Italy & 220 & 240 & 260 & 300 & 315 & 345 & 455 \\
\hline Netherlands & 270 & 320 & 385 & 470 & 570 & 610 & 740 \\
\hline Norway & 185 & 225 & 285 & 340 & 430 & 475 & 615 \\
\hline Portugal & 230 & 250 & 275 & 290 & 295 & 320 & 335 \\
\hline Romania & 190 & 195 & 205 & 225 & 265 & 300 & 370 \\
\hline Russia & 170 & 180 & 190 & 220 & 210 & 260 & 340 \\
\hline Serbia & 185 & 200 & 215 & 235 & 260 & 270 & 300 \\
\hline Spain & 210 & 250 & 295 & 315 & 325 & 365 & 400 \\
\hline Sweden & 195 & 235 & 270 & 315 & 405 & 495 & 705 \\
\hline Switzerland & 190 & 240 & 340 & 485 & 645 & 730 & 875 \\
\hline Average & 200 & 235 & 285 & 350 & 420 & 480 & 580 \\
\hline Standard deviation & 24 & 44 & 68 & 110 & 155 & 182 & 227 \\
\hline
\end{tabular}




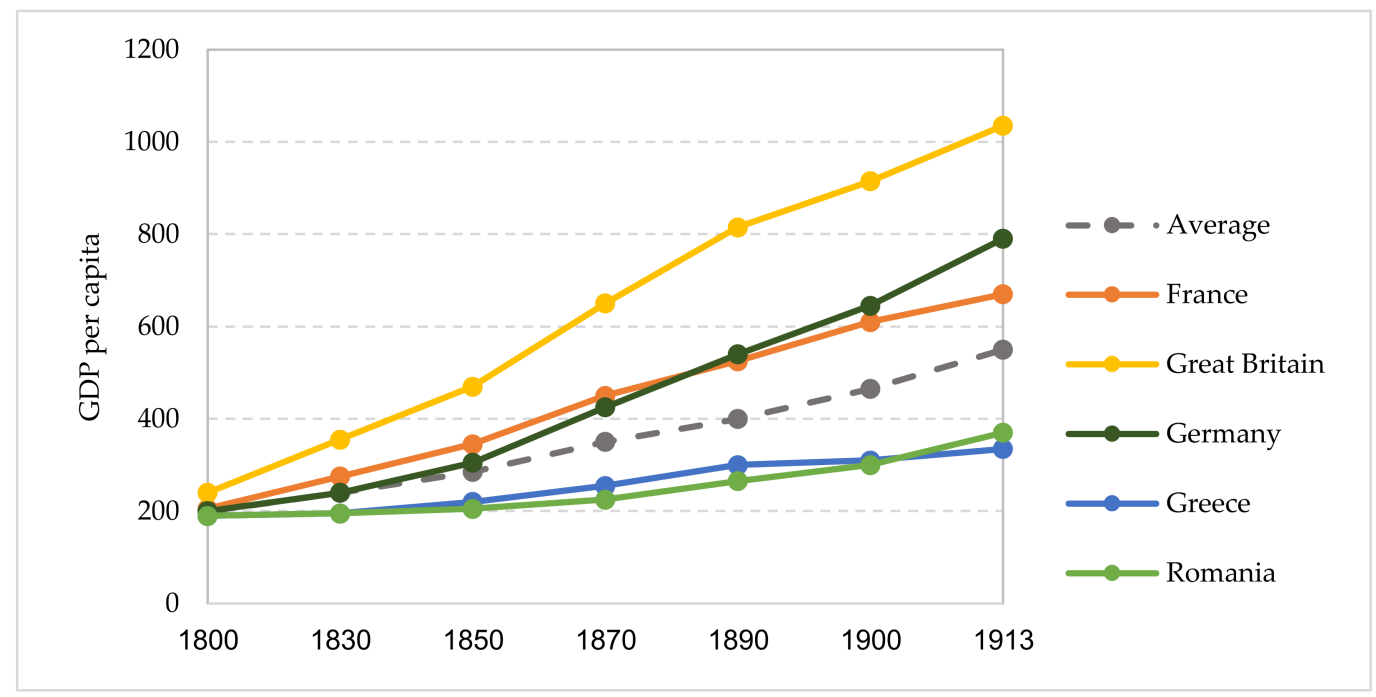

Figure 2. Dynamics of the GDP per capita in European countries marked by the Industrial Revolution.

The differences between states in terms of development generated by the Industrial Revolution are noticeable. Thus, if in 1800 the standard deviation of GDP per capita was only 24, at the beginning of the 20th century, in 1913, it reached 229. The results were, undoubtedly, the consequence of the gap in industrialisation between Great Britain ("the workshop of the world") and the other states. For most countries, the values remained low for various reasons (e.g., Russia).

Noticeably, beyond all the delays in assimilating technological progress related to the Industrial Revolution, differentiated economic growth was explained by regions' social, economic, political and natural specificities, reflected in the pace and periods in which the railway networks expanded. Figure 3 illustrates the significant differences among the average annual growth rates of GDP per capita in the different periods retained in the analysis. Among the selected countries, Romania was the only one with continuity of increasing annual growth rates (between 1830 and 1913).

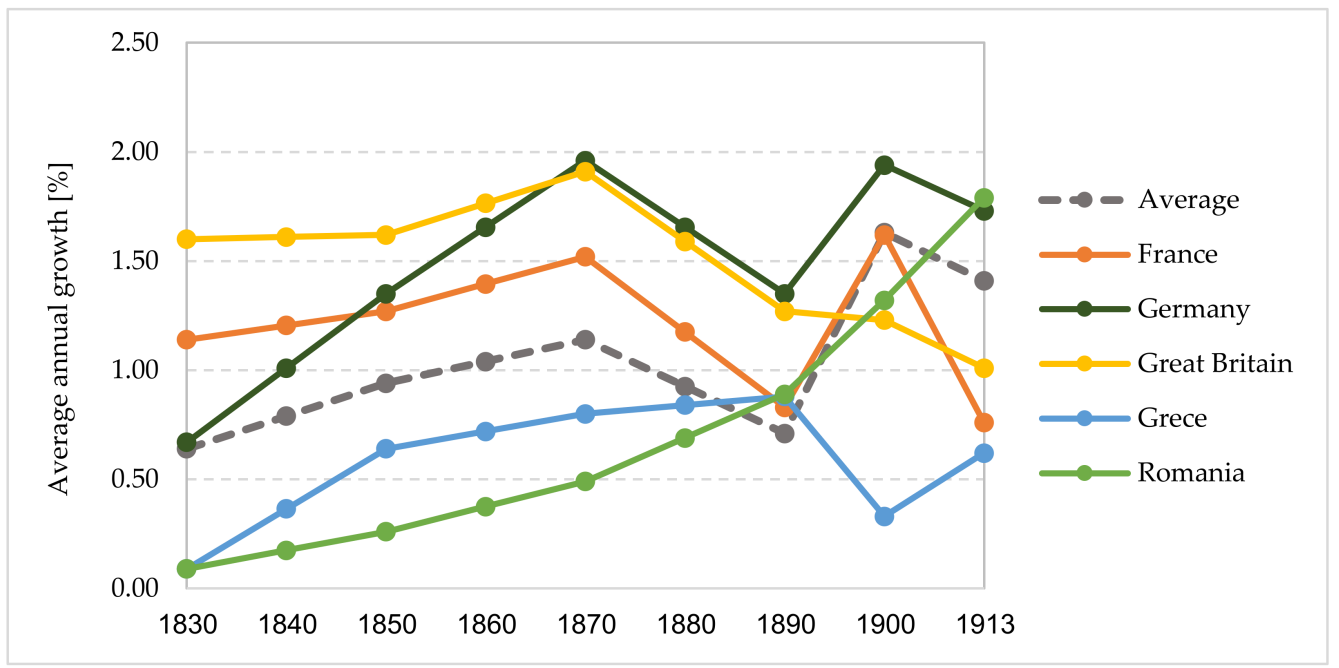

Figure 3. Comparative dynamics of average increasing rates of GDP per capita in industrialised and predominantly agricultural countries.

The marked specificity of the first steps of constructing the railway network in Romania could explain this fact. Completed in the last decades of the 19th century, the 
railway connections with the Danube ports and with the Black Sea allowed for the gradual capitalisation of the export of the increased productivity achieved in agriculture (Figure 4).

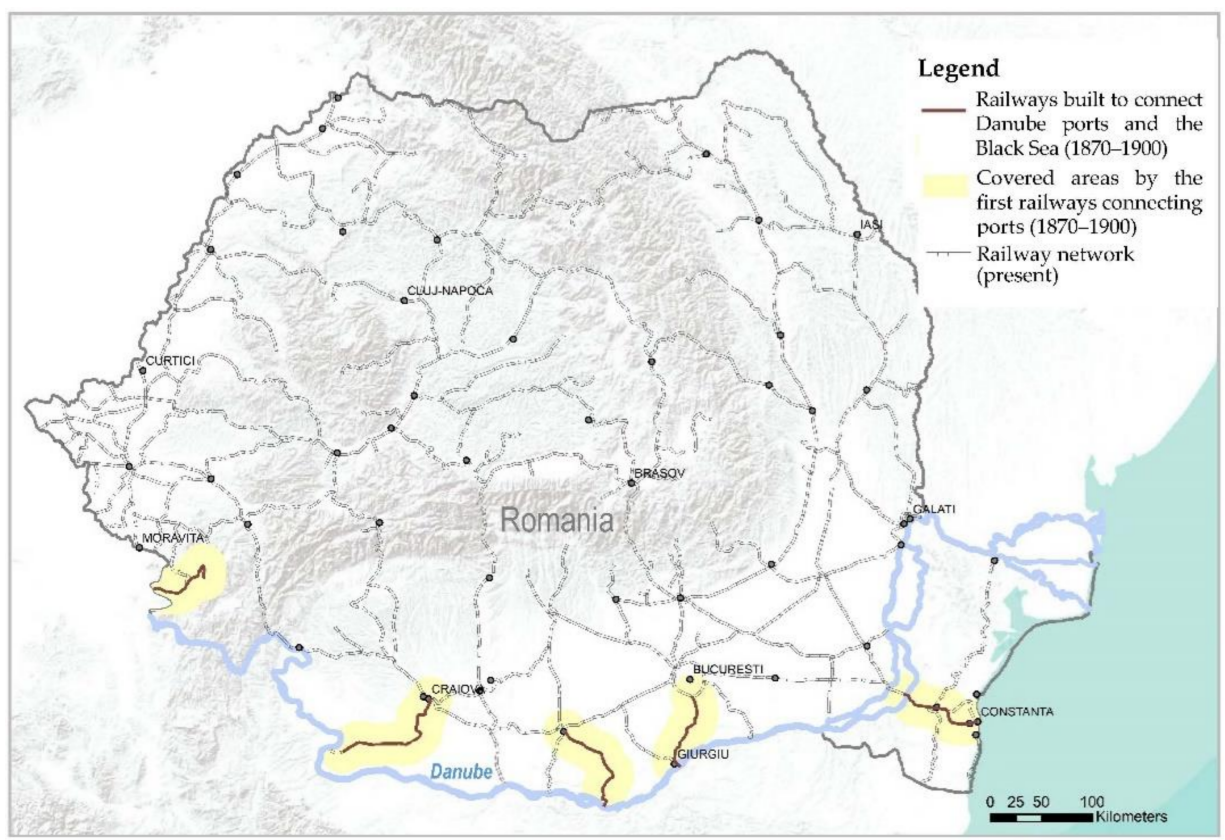

Figure 4. Railway links with the Danube ports and the Black Sea built in Romania (last decades of the 19 th century).

If in other European countries the building of railways was the consequence of the requirements of the machinist revolution (an effect of the level reached in industrial development), then, in the case of Romania, the railway construction preceded industrialisation and was entirely financed by the state.

In addition to the role played in stimulating exports, the emergence of new settlements and the increase in the spatial mobility of the population (with effects on direct cognisance of the land), the railways contributed to the professionalisation of labour and, subsequently, generated the sources of industrial growth. The significance of railway transport could be revealed by the fact that in 1906, the installed power of the locomotives in operation was $350,000 \mathrm{hp}$, i.e., seven times greater than the installed capacity of the entire Romanian industry in that period. However, until the end of the 19th century, economic aspects could not sustain the investments in Romanian railways (poorer return of investment, oversized transport capacity and the need for significant state subsidies for operation). But even so, that transport infrastructure undoubtedly had positive consequences for the economic and social development of the country [70].

Table 2 underlines the two periods of economic evolution of society recorded by historians and economists for the period from the early 19th century to the First World War, namely, that of the confirmation of the Industrial Revolution (1820-1870) and that of the apogee (1870-1913). In the first period, the income per capita in West European countries increased by approximately $1 \%$. However, that increase could be considered substantial compared to the growth rate of $0.14 \%$ between 1500 and 1820 [69].

Around 1870, the development of capitalism accelerated. Technological innovations from 1860 to 1910 led to the development of heavy and chemical industries: electric cars, internal combustion engines, synthetic paints, artificial fertilisers, etc. Unlike the technologies of the Industrial Revolution invented mainly by practical, intuitive people, systematic application of scientific and engineering principles developed new technologies. Consequently, any applied/invented technological progress with confirmed efficiency could be copied and used very rapidly. In addition, systems of mass production of assembly 
lines were developed. The average growth rate accelerated to $1.3 \%$ (compared to $1 \%$ between 1820 and 1870).

Figure 5a displays the differentiated averages of the annual growth rate of GDP per capita in industrialised countries (e.g., Great Britain, Germany and France) and countries with other economic structures (e.g., Greece and Romania) for 1800-1913. Figure 5b separates the annual growth rate averages for the two mentioned periods: 1800-1870 and 1870-1913, respectively. In the second period, Figure 5b shows a decrease in the averages for the countries that assimilated machinism more quickly (Great Britain but also France), as opposed to Germany, which recorded an increased average. In the second period (1870-1913), the average leap recorded by Romania was noticeable. But in that case, the rise could not be associated with intensive industrialisation but rather with the increase in the productivity in the primary sectors (mainly extraction and agriculture) and export opportunities.

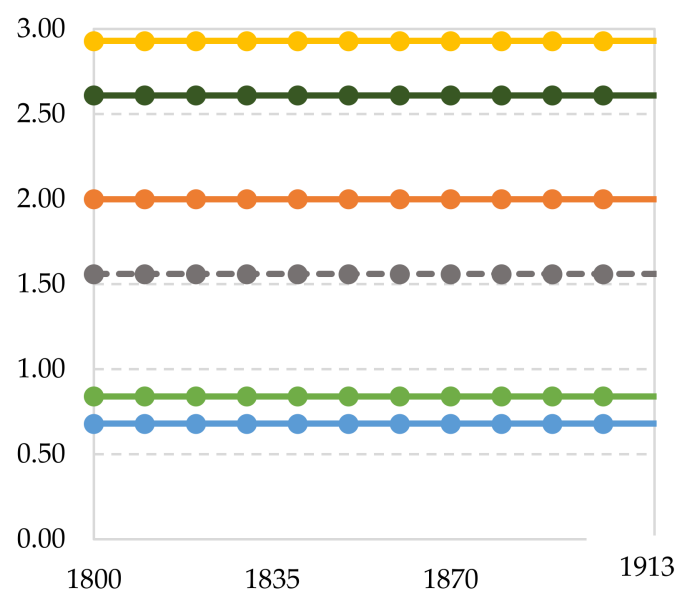

(a)

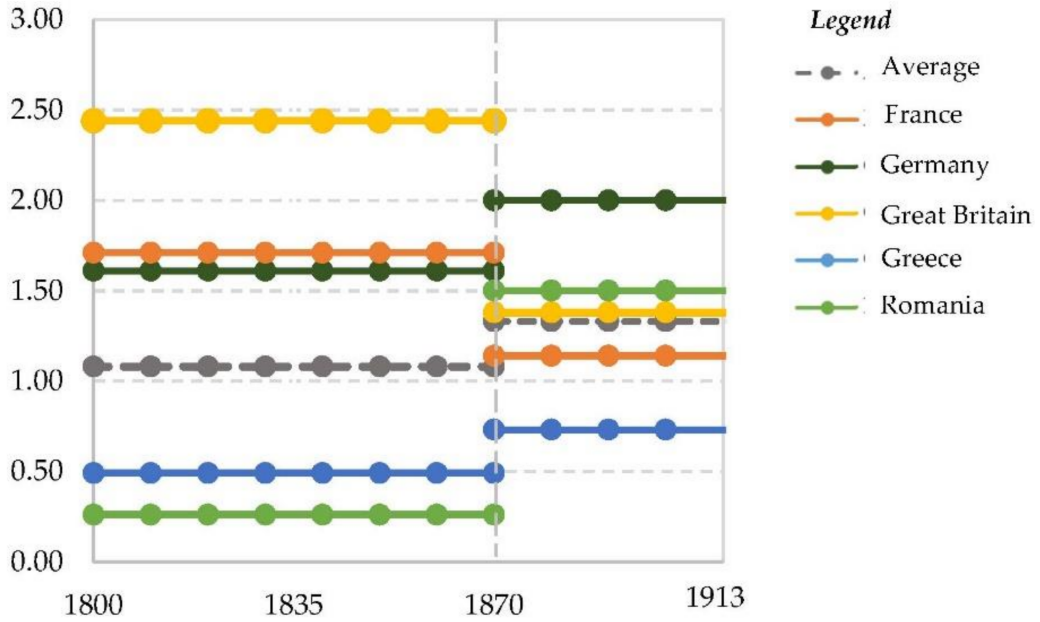

(b)

Figure 5. Averages of the increasing rates of GDP per capita: (a) average for the period 1800-1913 (\%); (b) averages for the period 1800-1870, respective 1870-1913 (\%).

Definitely, the analysis does not intend to identify the causes that determined the economic growth, revealed by the GDP per capita in the mentioned countries. The aim was to reveal the correlated evolution of economic growth-territorial system-traffic infrastructures, respectively, and the role of traffic infrastructure on the territorial dynamics.

It should be noted that quantitative assessments of the effects of investment in the traffic infrastructure on territorial economic growth using Cobb Douglas or Translog production functions (initiated at the beginning of the 20th century) have failed to obtain convincing results $[1,6,28,30,71,72]$. The difficulty in selecting only independent factors could be one of the leading causes of cancelling such models.

However, regardless of the imperfection of the applied mathematical models, it would be illusory to affirm that the causal chain for social change could be identified based on one or two factors (e.g., technological, capital and/or labour). Only the interactions among the multitude of factors considered in the social sciences could explain the transformation of society [73]. However, it is difficult to synthesise these interactions into a quantitative model. Therefore, identifying an optimal level of traffic infrastructure in a territory remains an open issue.

\section{Conclusions}

It is commonly accepted that traffic infrastructure networks have a fundamental role in land use, but the problem of correlations between infrastructure investments and 
stimulated territorial development continues to be a controversial topic, open to research and of significant interest to the public authorities.

The role of traffic infrastructure in development is conditioned by the manner of analysis of traffic infrastructure and the territory and the theoretical representation of the development. Both approaches reveal a diversity of particularities that limit the possibility of formulating general conclusions on the correlations between traffic infrastructures and development.

Relative to different periods and subjects, there is a polysemy around the concept of land/territory. Differences appear even from how the requirements of sustainable development transpose into the operational procedures in each territory. These differences should be considered. If it is acknowledged that development objectives are not the same everywhere, then the concept of development must be defined more broadly. Quality of life, the synthetic expression of development, is not limited to GDP per capita. It is extended to composite indicators that reflect the social welfare of the population in a territory (education, life expectancy, equitable access to resources and equipment, method of income distribution, etc.).

In general terms, traffic infrastructure and transport services (designed to ensure accessibility to places of interest in a territorial system) are decisive for traffic flow sizes and physical structures. However, their generation depends on the nature, structure and extent of the activities of the territorial system.

Traffic infrastructure is not a good premise for stimulating a positive economic and social dynamic. It is only one of the factors that condition the development of the territorial system by improving accessibility. Further, development depends on invisible and intangible sources that actions in favour of innovation must arouse. Technological innovations and trade initiatives are essential conditions. Increasing infrastructure performance has a positive effect on development when the potential for development already exists in its area of influence.

Due to the improved accessibility, a new infrastructure expands the market area and increases competition and, possibly, infrastructure development may not lead to local development. The area separation (before the increase in local accessibility) could protect the local market from external competition. Therefore, new traffic infrastructure may not induce development but even inhibit regional growth. Consequently, before constructing traffic infrastructure, each region must detect the beneficial sectors for development and act accordingly in advance.

The specific traffic infrastructure that facilitates sustainable mobility needs to be identified, namely, the infrastructure that will maximise the requirements of sustainable development-economic, social and environmental.

The expected evolutions in the use of intelligent vehicles (reducing almost wholly the driver's role) will also be reflected in the performance of the land's infrastructure, especially the road infrastructure (by increasing traffic capacity and traffic safety). The environmental requirements for land mobility are increasingly acute. In that case, changes must be foreseen in policies of development and use of traffic infrastructures and management of the correlations with other technical infrastructures of society.

Author Contributions: Conceptualisation, S.R.; methodology, S.R. and D.C.; software, D.C.; validation, S.R., M.P. and V.D.; formal analysis, S.R. and D.C.; investigation, S.R., D.C., M.P. and V.D.; resources, M.P., and V.D.; writing-original draft preparation, S.R. and D.C.; writing-review and editing, S.R., D.C., M.P. and V.D. All authors have read and agreed to the published version of the manuscript.

Funding: This research received no external funding.

Conflicts of Interest: The authors declare no conflict of interest. 


\section{References}

1. Fritsch, B.; Prud'homme, R. Measuring the Contribution of Road Infrastructure to Economic Development in France in Econometrics of Major Transport Infrastructures. In The Econometrics of Major Transport Infrastructures. Applied Econometrics Association Series; Quinet, E., Vickerman, R., Eds.; Palgrave Macmillan: London, UK, 1997; pp. 45-67. [CrossRef]

2. Meunier, C. Infrastructures des transport et développement. L'apport de l'économie des réseaux. Les Cah. Sci. Transp. 1999, 36, 69-85.

3. Plassard, F. Transport et Territoire; Predit La Documentation Française: Paris, France, 2003.

4. Moine, A. Le territoire comme un système complexe: Un concept opératoire pour l'aménagement et la géographie. L'Espace Géogr. 2006, 35, 115-132. [CrossRef]

5. ITF. Understanding the Value of Transport Infrastructure Guidelines for Macro-Level Measurement of Spending and Assets Research Report. International Transport Forum: OECD. 2013. Available online: https://www.itf-oecd.org/understandingvalue-transport-infrastructure (accessed on 30 July 2021).

6. Fritsch, B. La Contribution des Infrastructures au Développement des Régions Françaises; Presses de l’École Nationale des Ponts et Chaussées: Paris, France, 1999.

7. Gnap, J.; Varjan, P.; Durana, P.; Kostrzewski, M. Research on relationship between freight transport and transport infrastructure in selected european countries. Transp. Probl. 2019, 14, 63-74. [CrossRef]

8. Baum-Snow, N.; Henderson, J.V.; Turner, M.A.; Zhang, Q.; Brandt, L. Does investment in national highways help or hurt hinterland city growth? J. Urban Econ. 2020, 115, 103124. [CrossRef]

9. García-Olivares, A.; Solé, J.; Samsó, R.; Ballabrera-Poy, J. Sustainable European Transport System in a 100\% Renewable Economy. Sustainability 2020, 12, 5091. [CrossRef]

10. Henke, I.; Cartenì, A.; Molitierno, C.; Errico, A. Decision-Making in the Transport Sector: A Sustainable Evaluation Method for Road Infrastructure. Sustainability 2020, 12, 764. [CrossRef]

11. Llorca, C.; Silva, C.; Kuehnel, N.; Moreno, A.; Zhang, Q.; Kii, M.; Moeckel, R. Integration of Land Use and Transport to Reach Sustainable Development Goals: Will Radical Scenarios Actually Get Us There? Sustainability 2020, 12, 9795. [CrossRef]

12. Straub, S. Infrastructure and Growth in Developing Countries: Recent Advances and Research Challenges; Policy Research Working Papers; World Bank: Washington, DC, USA, 2008; Volume 4460, Available online: https:/ / openknowledge.worldbank.org/ handle/10986/6458 (accessed on 21 June 2021).

13. Blanquart, C.; Joignaux, G.; Vaillant, L. Infrastructure de transport et développement économique: Quelles dynamiques d'appropriation par les acteurs productifs ? L'exemple de la filière céréalière autour du canal Seine-Nord Europe. Rev. D'écon. Rég. Urbaine 2013, 1, 119-138. [CrossRef]

14. Daviet, S. L'évolution du concept d'innovation: Entrepreneurs, territoires et réseaux. Cah. Nantais 2005, 62-63, 5-13.

15. Bérion, P.; Joignau, X.; Langumier, J.-F. L'évaluation socio-économique des infrastructures de transport: Enrichir les approches du développement territorial. Rev. D'écon. Rég. Urbaine 2007, 4, 651-676. [CrossRef]

16. Cascetta, E.; Carteni, A.; Montanino, M. Decision-making processes in transportation planning: A taxonomy and four theoretical models. In The Decision-Making Process for Infrastructural Investment Choices; Venezia, E., Ed.; Franco Angelli: Milano, Italy, 2019; pp. 112-141.

17. Palei, T. Assessing the Impact of Infrastructure on Economic Growth and Global Competitiveness. Procedia Econ. Financ. 2015, 23, 168-175. [CrossRef]

18. Kirat, T.; Levratto, N. Tous égaux face aux nuisances des infrastructure de transport? Le calcul économique et le droit administratif au défi de l'équité. Géogr. Écon. Soc. 2008, 3, 350-364. [CrossRef]

19. Raicu, S.; Costescu, D. Mobility. Traffic Infrastructures; AGIR Press: Bucharest, Romania, 2020. (In Romanian)

20. Kolodko, G.W. Whither the World: The Political Economy of the Future; Palgrave Macmillan: London, UK, 2014; Volume 2. [CrossRef]

21. Ouvard, J.F. Judes A. Investir Dans les Infrastructures Pour la Croissance; Document de Travail N. 54; Coe-Rexecode: Paris, France, 2015; Available online: http:/ / www.rexecode.fr/public/Analyses-et-previsions/Documents-de-travail/(annee)/2015 (accessed on 23 June 2021).

22. Faith-Ell, C.; Fischer, T.B. Strategic environmental assessment in transportation planning. In Handbook on Strategic Environmental Assessment; Fischer, T.B., Ed.; Edward Elgar Publishing: Cheltenham, UK, 2021.

23. Varlet, J. Géographes et recherche finalisée: Les observatoires d'autoroutes en France. Flux 2000, 3, 46-49. [CrossRef]

24. Macario, R.; Carvalho, D.; Fermisson, J. Achieving sustainable transport and land use with integrated policies. In Urban Transport XI. Urban Transport and the Environment in the 21st Century; Brebbia, C.A., Wadhwa, L., Eds.; WIT Press: Southampton, UK, 2005; Volume 77, pp. 351-360. [CrossRef]

25. Stafford-Smith, M.; Griggs, D.; Gaffney, O.; Ullah, F.; Reyers, B.; Kanie, N.; Stigson, B.; Shrivastava, P.; Leach, M.; O'Connell, D. Integration: The key to implementing the Sustainable Development Goals. Sustain. Sci. 2017, 12, 911-919. [CrossRef]

26. Russo, F. Which High-Speed Rail? LARG Approach between Plan and Design. Futur. Transp. 2021, 1, 202-226. [CrossRef]

27. Markvica, K.; Hu, B.; Prandtstetter, M.; Ritzinger, U.; Zajicek, J.; Berkowitsch, C.; Hauger, G.; Pfoser, S.; Berger, T.; Eitler, S.; et al. On the Development of a Sustainable and Fit-for-the-Future Transportation Network. Infrastructures 2018, 3, 23. [CrossRef]

28. Aschauer, D.A. Is public expenditure productive? J. Monetary Econ. 1989, 23, 177-200. [CrossRef]

29. Börjesson, M.; Jonsson, R.D.; Berglund, S.; Almström, P. Land-use impacts in transport appraisal. Res. Transp. Econ. 2014, 47, 82-91. [CrossRef] 
30. Crescenzi, R.; Rodríguez-Pose, A. Infrastructure and regional growth in the European Union. Pap. Reg. Sci. 2012, 91, 487-513. [CrossRef]

31. Agbelie, B.R. An empirical analysis of three econometric frameworks for evaluating economic impacts of transportation infrastructure expenditures across countries. Transp. Policy 2014, 35, 304-310. [CrossRef]

32. Lakshmanan, T. The broader economic consequences of transport infrastructure investments. J. Transp. Geogr. 2011, 19, 1-12. [CrossRef]

33. Skorobogatova, O.; Kuzmina-Merlino, I. Transport Infrastructure Development Performance. Procedia Eng. 2017, 178, 319-329. [CrossRef]

34. Hasselgren, B. Transport Infrastructure in Time, Scope and Scale. An Economic History and Evolutionary Perspective; Palgrave Macmillan: London, UK, 2018. [CrossRef]

35. Capra, F. The Turning Point: Science, Society, and the Rising Culture, Reissue ed.; Bantam Press: London, UK, 1984.

36. Rungskunroch, P.; Jack, A.; Kaewunruen, S. Socioeconomic Benefits of the Shinkansen Network. Infrastructures 2021, 6, 68. [CrossRef]

37. Eliasson, J.; Savemark, C.; Franklin, J. The impact of land use effects in infrastructure appraisal. Transp. Res. Part A Policy Pract. 2020, 141, 262-276. [CrossRef]

38. West, G. Scale: The Universal Laws of Growth, Innovation, Sustainability, and the Pace of Life in Organisms, Cities, Economies, and Companies; Penguin Press: New York, NY, USA, 2017.

39. Macario, R. Tracing factors for quality of decision in transport infrastructure investment. In The Decision-Making Process for Infrastructural Investment Choices; Venezia, E., Ed.; Franco Angelli: Milano, Italy, 2019; pp. 95-111.

40. Geurs, K.T.; van Wee, B. Accessibility evaluation of land-use and transport strategies: Review and research directions. J. Transp. Geogr. 2004, 12, 127-140. [CrossRef]

41. Litman, T. Measuring Transportation: Traffic, Mobility and Accessibility. ITE J. 2003, 7, $28-32$.

42. Xi, Y.; Miller, E.J.; Saxe, S. Exploring the Impact of Different Cut-off Times on Isochrone Measurements of Accessibility. Transp. Res. Rec. J. Transp. Res. Board 2018, 2672, 113-124. [CrossRef]

43. Stewart, A.F.; Zegras, P.C. CoAXs: A Collaborative Accessibility-based Stakeholder Engagement System for communicating transport impacts. Res. Transp. Econ. 2016, 59, 423-433. [CrossRef]

44. Offner, J.M. Le développement des réseaux techniques: Un modèle générique. Flux 1993, 13-14, 11-18. [CrossRef]

45. Madsen, J.B. A century of economic growth: The social returns to investment in equipment and structures. Manch. Sch. 2005, 73, 101-122. [CrossRef]

46. Klenert, D.; Mattauch, L.; Edenhofer, O.; Lessmann, K. Infrastructure and inequality: Insights from incorporating key economic facts about household heterogeneity. Macroecon. Dyn. 2018, 22, 864-895. [CrossRef]

47. Cascetta, E.; Cartenì, A.; Pagliara, F.; Montanino, M. A new look at planning and designing transportation systems: A decisionmaking model based on cognitive rationality, stakeholder engagement and quantitative methods. Transp. Policy 2015, 38, 27-39. [CrossRef]

48. Gramlich, E. Infrastructure Investment: A Review Essay. J. Econ. Lit. 1994, 32, 1176-1196.

49. Parthasarathi, P.; Levinson, D. Post-construction evaluation of traffic forecast accuracy. Transp. Policy 2010, 17, 428-443. [CrossRef]

50. Farhadi, M. Transport infrastructure and long-run economic growth in OECD countries. Transp. Res. Part A Policy Pract. 2015, 74, 73-90. [CrossRef]

51. Chen, A.; Li, Y.; Ye, K.; Nie, T.; Liu, R. Does Transport Infrastructure Inequality Matter for Economic Growth? Evidence from China. Land 2021, 10, 874. [CrossRef]

52. HHurlin, C. Network Effects of the Productivity of Infrastructure in Developing Countries; Policy Research Working Paper; World Bank: Washington, DC, USA, 2006; Volume 3808, Available online: https:/ / openknowledge.worldbank.org/handle/10986/8836 (accessed on 21 June 2021).

53. Estache, A. Emerging Infrastructure Policy Issues in Developing Countries: A Survey of the Recent Economic Literature; Policy Research Working Paper; World Bank: Washington, DC, USA, 2004; Volume 3442, Available online: https: / / openknowledge.worldbank org/handle/10986/14220 (accessed on 21 June 2021).

54. Lakhera, M.H. Economic Growth in Developing Countries. Structural Transformation. Manufacturing and Transport Infrastructure; Palgrave Macmillan: London, UK, 2016. [CrossRef]

55. Zartarian, V. Les Grandes Civilisations; Georg: Kreuztal, France, 2003.

56. Chang, H.J. Economics: The User's Guide; Pelican: Minnetonka, MN, USA, 2014.

57. Toynbee, A.J. Cities on the Move, 1st ed.; Oxford University Press: Oxford, UK, 1970.

58. Marechal, J.P. Développement durable. In Dictionnaire de L'autre Economie; Cattani, A.D., Laville, J.L., Eds.; Desclée de Brouwer: Paris, France, 2005; pp. 125-133.

59. Huchet, J.-F.; Maréchal, J.-P. Éthique et modèle de développement: L'avenir du climat au défi de la croissance économique chinoise. Géoéconomie 2008, 44, 33-58. [CrossRef]

60. Madsen, J.B. Human Capital and the World Technology Frontier. Rev. Econ. Stat. 2014, 96, 676-692. [CrossRef]

61. Coloma, J.F.; García, M.; Pascual-Pedreño, E. Effects of Rail Freight Corridors in Low Population Regions. Futur. Transp. 2021, 1, 466-485. [CrossRef] 
62. Ke, X.; Lin, J.; Fu, C.; Wang, Y. Transport Infrastructure Development and Economic Growth in China: Recent Evidence from Dynamic Panel System-GMM Analysis. Sustainability 2020, 12, 5618. [CrossRef]

63. Şahan, D.; Tuna, O. Policy Implications on Transport Infrastructure-Trade Dynamics: Case of Turkey. Logistics 2021, 5, 47. [CrossRef]

64. Boopen, S. Transport Infrastructure and Economic Growth: Evidence from Africa Using Dynamic Panel Estimates. Empir. Econ. Lett. 2006, 5, 37-52.

65. Välilä, T. Infrastructure and growth: A survey of macro-econometric research. Struct. Chang. Econ. Dyn. 2020, 53, 39-49. [CrossRef]

66. Thisse, J.F. Equité, efficacité et acceptabilité dans localisation des équipements collectifs. In Le Calcul Économique Dans le Processus de Choix Collectif des Investissements de Transport; Maurice, J., Crozet, Y., Eds.; Predit Economica: Paris, France, 2007 ; pp. 361-401.

67. Varjan, P.; Rovnanikova, D.; Gnap, J. Examining Changes in GDP on the Demand for Road Freight Transport. Proc. Eng. 2017, 192, 911-916. [CrossRef]

68. Delong, J.B.; Summers, L.H. Fiscal Policy in a Depressed Economy. Brookings Pap. Econ. Act. 2012, 2012, 233-297. [CrossRef]

69. Bairoch, P. Victoires et Déboires. Histoire Économique et Social du Monde du XVI-e Siècle a Nos Jours; Folio: Paris, France, 1997; Volume 2.

70. Popescu, T. The Romanian Railway Project (1842-1916); Simetria: Bucharest, Romania, 2014. (In Romanian)

71. Prud'homme, R. Assessing the Role of Infrastructure in France by Means of Regionally Estimated Production Functions. In Infrastructure and the Complexity of Economic Development; Batten, D.F., Karlsson, C., Eds.; Springer: Berlin/Heidelberg, Germany, 1996; pp. 37-47. [CrossRef]

72. Baldwin, J.R.; Dixon, J. Infrastructure Capital: What Is It? Where Is It? How Much of It Is There? Canadian Productivity Review. 15-206-X-No. 16; Micro-Economic Analysis Division, Statistics Canada: Ottawa, ON, Canada, 2008; Available online: https: // papers.ssrn.com/sol3/papers.cfm?abstract_id=1507883 (accessed on 4 October 2021).

73. Kamps, C. The Dynamic Effects of Public Capital: VAR Evidence for 22 OECD Countries. Int. Tax Public Finance 2005, 12, 533-558. [CrossRef] 